Renaissance. But the nation's cultural respect for study never died.

Science regained its foothold during the 1970s, under the Shah, even though his oppressive regime drove many intellectuals into exile. It faltered at the start of the Islamic revolution in 1979, but gained momentum in the 1990s when Iran became the most scientifically productive country in the Middle East apart from Israel. About 4,000 papers from Iran were published in 2005, according to the Institute for Scientific Information, compared with just over 500 in 1995. (Nature's first all-Iranian research paper was published last week.)

Perhaps the rise of science relates to the importance that Iran's government attaches to the development of nuclear technology. Many regard Iran's interest in these technologies with extreme suspicion. Nonetheless, Iran's embrace of science should be welcomed.

The educated young in Iran will still go their own individual ways, usually for good, sometimes for bad. But there is once again the opportunity for a privileged few to shine as scientists, if they can cope with the low pay and poor infrastructure that prevail outside the handful of elite institutions, and can sidestep the many problems caused by US sanctions.

One practical advantage for science in Muslim countries is the lack of direct interference of religious doctrine, such as exists in many Christian countries. There has never, for example, been a debate about darwinian evolution, and human embryonic stem-cell research is constrained by humanistic rather than religious ethics. The Royan Institute in Iran was the first in the Middle East to develop a human embryonic stem-cell line, using spare embryos from its in vitro fertilization programme.

The recent dramatic rise in scientific productivity coincided with the relaxing of a stern Islamic regime under reformist president Mohammad Khatami. When hard-line Islamist Mahmoud Ahmadinejad was elected president last year, some scientists felt nervous, especially, no doubt, when he replaced the presidents of all the universities with worryingly inexperienced people. But the regime has so far shown a strong commitment to higher education. One of its first acts was to wipe out the debts accrued by universities, where female students now outnumber males, even in some areas of hard science. Ahmadinejad has also taken significant steps to prepare for an expansion of university student numbers. And he has not made cuts to research funds, which had increased over the past decade.

But will he maintain growth, given other pressing priorities in today's Iran? If not, many young scientists trained in the recent good years and now undertaking postdoctoral research abroad will have no prospects if they return home. An opportunity would be lost. So here's hoping that he avoids the need for these lines of Khayyam as a lament:

Alas that spring should vanish with the rose

That youth's sweet-scented manuscript should close!

\section{Preventing cancer}

\section{More support is required to tackle obesity as a means of cancer prevention.}

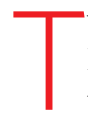
wenty-five years ago, a landmark study by Richard Doll and Richard Peto concluded that $75-80 \%$ of cancers diagnosed in the United States in 1970 might theoretically have been prevented by altering environmental factors such as smoking, alcohol consumption and diet (R. Doll \& R. Peto J. Natl Cancer Inst. 66, 1191-1308; 1981). More recent work has added obesity and physical inactivity to the list of factors that increase cancer risk. Today, tobacco use accounts for $30 \%$ of cancers in the United States, obesity accounts for $15 \%$ and poor diet for up to $25 \%$. Clearly, while avidly pursuing promising avenues of therapy (see page 735), the biomedical community and policy-makers need to tackle cancer prevention with just as much zeal.

The success of campaigns to combat melanoma and lung cancer are testaments to the impact that prevention can make. For example, the Australian government's exhortation to "slip on a shirt, slop on a sunscreen, slap on a hat" has led to melanoma having less of a health impact in Australia than in cloudier countries such as Britain. The incidence of smoking-related cancers has dropped sharply since the 1990s - the delayed effects of anti-smoking campaigns started in the 1960s and 1970s.

But much still needs to be done. Tobacco remains a problem, especially in the developing world, where consumption is climbing. The next biggest threat facing the developed world is the growing epidemic of obesity. In the United States and Europe, for example, around two-thirds of the population is either overweight or obese. Research into how people form dietary and exercise habits will help to inform intervention campaigns, and research on nutrition will help to determine why a vegetable-rich, low-saturated-fat diet seems to provide protection against cancer. Studies on genetic susceptibility could one day help us all to tailor our lifestyles to suit our risk profiles.

But such research is likely to have little effect unless policy-makers are prepared to go further than just educating the public. Avoiding the Sun is straightforward and cheap. The same cannot be said of factors that affect obesity. Once associated with wealth and excess, obesity now disproportionately affects the poorer sections of society, because high-calorie, low-nutrient, processed food is often much more easily accessible than healthy alternatives. Governments need to help ensure that eating the recommended five portions of fruit and vegetables a day is a realistic aim for everyone.

Physical activity needs to be tack-

\section{"The success of campaigns to combat melanoma and lung cancer are testaments to the impact that prevention can make."} led too. Encouraging children and adults to take up sport is a start, but policies that encourage people to build exercise into their daily lives - town planning that makes walking to the shops or cycling to work easier and safer, for example - are likely to have a longerlasting impact.

Our modern lifestyles are increasingly at odds with the environment in which our physiology originally evolved. Finding a truce between the two would go a long way to reducing the burden of diseases, such as cancer, that result. 